\title{
A Study on Participation in Decision Making Among Members of Quality Circle in Manufacturing Companies
}

\author{
${ }^{1}$ S.Subbulakshmi, ${ }^{2}$ Dr.S.K.Nagarajan, ${ }^{3}$ Dr.A.John William Felix, \\ ${ }^{1,2}$ Assistant Professor Department of Business Administration, Annamalai University, Chidambaram, \\ Tamilnadu, India. \\ ${ }^{3}$ Reader-Cum-StatisticianDepartment of Community Medicine, Annamalai University, Chidambaram, \\ Tamilnadu, India.
}

\begin{abstract}
The world of business is changing with multiple resources to establish them as the paramount in aggressive period. No individuals can achieve this aggressive era independently, so they need the support of technology and human resources. There are numerous systems to operate technology, butthe issue is effective utilization of human resources and it is also considered as valuable asset in business to attain competition. Human resources can be effectively utilized through participative management and this could be achieved by implementing quality circle in organisation. Employee participate in decision making of management through quality circle, this study is about participation in decision making among members of quality circle in manufacturing companies and to identify variables which influencing participation. Though there are many variables which influence participation in decision making, researcher have chosen attitudes of quality circle, training and length of membership as influencing factors. Data collected from quality circle members of manufacturing companies through standard questionnaire and toidentify the interrelationship between variables structural equation model have been performed by using AMOX software. Results emerging from analysis show that there is significant relationship between all four variables. Finally the article provides suggestions to improve participation in decision making of employees still effectively.
\end{abstract}

Keywords: participative management, quality circle, participation in decision making, attitudes of $Q C$

\section{Introduction}

In order to compete in globalized market participation of employee in decision making is more important and it is not simple task to make them involve. This can be made possible with implementing quality circle; itis a recognized, institutionalized system for productive and participative problem solving technique among the employees of an organization. Quality circles consists of small group of employees from all levels of the existing hierarchical structure within an organization, voluntarily involved in the process of identifying, analyzing and formulating solutions to various technical, manual and automation related problems encountered in daily work life of a organisation. Anorganisation with effective implementation of quality circle will lead them to succeed in competitive world.

Once a particular organization adopts the practice of quality circle as part of work life, it is the foremost duty of the organization to orient and train its employees about their multiple roles as participants, facilitators and agents for change. Since it is a collective work of the employees, the success depends largely on the organization's support, members participation and role of organisation in knowledge dissemination among members of QCs.Successful quality circle help in upholding the morale, team spirit and participative partnership of the employees of organization, a visible and real support of organization is required to continue the quality circle process. It is observed that effective and efficient output from QCs improves the overall output of the organization in terms of production, manpower and quality of work life.As the suggestions of improvement is directly proposed by the employees based on their assessment and experience of every work (Maheshwari, 1987).The participation in decision making of quality circle members and management support play important role in success of QCs. The main purpose of this study is to gauge whether participation in decision making of QCs members is influenced by attitude of quality circle, training and length of participation because these factors have direct impact on participation of members in decision making(RajeshChaudhary 2012).This study reveals the relationship between participation in decision making, training, quality circle attitude and length of membership in quality circle.

\section{Objectives}

1. To assess influence of length of membership within training, quality circle attitude and participation in decision making among quality circle members in manufacturing companies

2. To measure level of influence between QCs attitude and training

3. To determine that attitude of QCs mediate between training and participation in decision making 
4. To establish the relationship between training and participation in decision making.

\section{Review Of Literature}

This study is about participation in decision making among members of quality circle in manufacturing companies and to identify variables which influencing participation. Though there are many variables which influence participation in decision making, researcher have chosen attitudes of quality circle, training and length of membership as influencing factors. To support the study reviews related to length of membership,attitudes of quality circle, training and participation in decision makingwere arranged in order

\section{Length of Membership}

Lawler and Mohrman (1987)to succeed QCs, it should be viable and effective over the long term, group participation should be institutionalized and considered "a way of life". Characteristics of workteams that promote institutionalization are mandated membership, decision-making authority, management involvement and support.

Griffin (1988) found that over a 3 year period, the effects of the quality circle program initially increased but then, after about 18 months, the level of effectiveness returned to its initial level. It is possible that after the novelty of the program had worn off, circle members began to lose interest in the program. Hefound that the decline in interest and enthusiasm was also evident on the part of management.

Dale, B. G (2000) the length of participation in QC process is considered as a measure that indicates the longevity of the program. This measure has been widely used to identify the effectiveness of the program. This also has to do with saying that QCs program is one of management fads which precisely described it as it is developed in a vague and previously undefined area. It is also saying that its users are initially enthusiastic about the program, albeit they can quickly lose interest if it turns out not to be as successful as envisaged at the outset.

\section{Attitude of quality circle}

Tortorich(1981) also found that quality circlesimprovedemployee attitudes. In a study at Martin Marietta Aerospace, found that participationin quality circles had a marked effect on such criteria as employee attitudes towards their jobs, their supervisors, and their co-workers.

Alexander (1981), the reason that some of the quality circles described in the previous studies were not very successful may have been because one or more of the requirements of quality circles were violated. The author lists these requirements as a commitment to people building, trust, and commitment to quality, open communication, supportive management, patience, training and development, a focus on results, supportive policies and procedures, and shared responsibilities. Alack of management support was cited most often as a causefor the lack of success in quality circle programs.

Atwater (1984), in their study of quality circles in the U.S.Navy, came to a conclusion that "the way quality circles are implemented and administered is critical" if they are to have a positive effect on the employees' attitudes.

Rajesh Chaudhary(2012)this study is an attempt to focus on the impact of quality circle towards employees and organization. It reveals that significance and perception of training with good leadership qualities are the success of quality circle in any organization. This study reveals and suggests that the positive attitude will be developed. It leads to overall improvement in organizational culture as well as performance of employees.

\section{Training}

Wood R,Hull F(1983) For the successful implementation of a QC program, employees have to be interested in the program and believe that their support and participation will benefit themselves as well as the organisation and participants in the QCs must be well trained in group dynamic and problem solving methodsthat are part of the QC technology.

Basu (2004) this study suggests that quality circles promote job involvement and a sense of participation. The supervisors identified problems and how to solve them according to their beliefs and understandings of the reality of the problem. They did not rely on outsiders such as educators or people from upper management. They participated in making decisions. The researcher also noted that quality circles encourage workers to become involved in making decisions that increase the quality of their work.

T R Abo-Alhol(2006)Participation in QC has some impact on workers. The training provided in QCs enable employees to develop skills and contribute in innovative ways. Generally the more training received, the higher the workers ability to solve problems. It also develops positive attitudes among employees. 


\section{Participation in Decision Making}

Shadur (1999) there is an assumption held by many scholars and managers that if employees are adequately informed about matters concerning them and are afforded the opportunity to make decisions relevant to their work, then there will be benefits for both the organisation and the individual.

PetrosPashiardis, (2000) in his study on teacher participation in decision making reveals thatteachers can take a greater role in the overall success of the school when they commit to being active participants in the decision-making process. Moreover, teachers need to feel they have more to offer to the school than just teaching within their classroom. Suggests that schools must understand that the entire system will benefit when teachers play an active role in controlling their work environment. Finally, everyone must be provided with as much recent research on participatory decision-making processes as possible before implementation can be achieved successfully. At the same time, specific training should also be provided.

RathnakarG. (2012) in his paper is concerned with an investigation of the existing level of Worker Participation in Management Decision making within the BHEL (Bharat Heavy Electrical Ltd.) environment. The study involved a survey in which a total of hundred non management employees drawn. Interview schedule and in-depth interview were the main research techniques adopted for data collection while percentage distribution and simple random sampling techniques were used to analyze the data collected for the study. Results show that employees in organizations demonstrate a high interest in participation in the decision making process within their respective work places.

\section{Operational Model And Hypothesis}

Figure 1.The linkage between training and participation in decision making

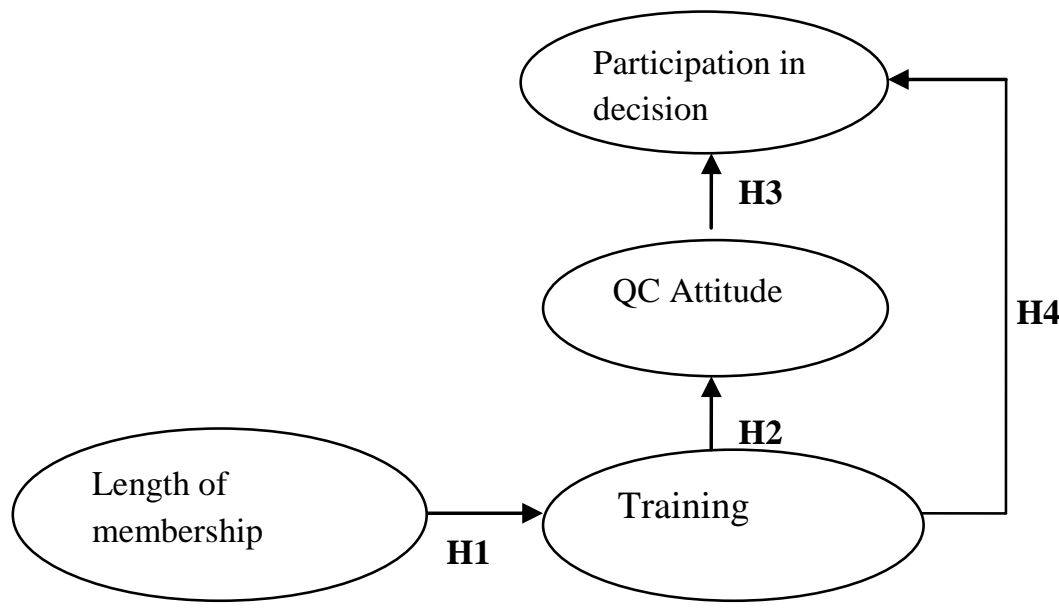

H1. Length of membership influence training in determining members participation in decision making.

$\mathrm{H} 2$. A relationship exists between training and QCs attitude.

H3. Improvements in QCs attitude mediate the relationship between training and participation in decision making.

H4. A positive relationship exists between training and participation in decision making

\section{Methodology}

Sample size: 50 employees of quality circle from three manufacturing companies in chennai have been chosen as population for this study

Sample technique: Respondents comprises of quality circle members in three manufacturing companies. Hence the population is 50 and from all the 50 data was collected for present study. Since all elements of population included the sampling technique is censored survey.

Area of Data collection: Quality circle members in three manufacturing companies in chennai district.

Data collection: The data is collected from both primary and secondary sources. Primary data is collected through standard questionnaire and the secondary data is collected from books, magazines, and websites etc.

\section{Research instrument}

The researcher have used three variable attitudes of quality circle, training and participation in decision making and used standard questionnaire for all the variables. Five items of Steel and Mento(1987) were used to measure participation in decision making. To measure training standard questionnaire of Choo\&Bowley (2007) 
was used in this study and to measure attitudes of quality circles researcher have used questionnaire framed by Lee 1.Shaw (1988).

\section{Statistical Analysis}

To test the raised hypotheses of the proposed framework the methodology of structural equation models (SEM) is used.

\section{Result And Discussion}

This section will highlight and discuss about the results and finding of the study. Theintention of this study is to determine whether participation in decision making of QCs members is influenced by attitude of quality circle, training and length of membership in selected manufacturing companies. Results emerging from analysis show that there is significant relationship between all four variables. The following table and its result will reveal the relationship between selected variables.

\section{Demographic variables}

For this study data were collected from members of quality circles in manufacturing companies, initially in this data analysis 40 percent of population are male and 10 percent of members are female. 40 percent of members are in the age group of 21 to 30,23 percent of employees are in age group of 31 to 40 and 7 percent of employee are between 41 to 50. 20 percent of employees are qualified in diploma level, 21 percent members are graduates and 19 percent of population are post graduates.38 percent of population are having experience below 5 years, 50 percent of members are having experience between 6 to 10 years, 8percent of members are having experience between 11 to 15 years and 4 percent of population have experience above 20 years

Table 1- Attitude of Quality Circle Members

\begin{tabular}{|l|l|l|}
\hline Level of attitudes & Frequency & Percentage \\
\hline Low level(<7) & 2 & 4 \\
\hline Moderate level(7 to11) & 25 & 50 \\
\hline High level(>11) & 23 & 46 \\
\hline
\end{tabular}

From the table 1 it is clear that 4 percent of population have low level of attitude about quality circle, 50 percent of members have moderate level of attitude towards quality circle and 46 percent of employees were having high level of attitude concerning quality circle.

Table 2-Length of Membership in Quality Circle Program

\begin{tabular}{|l|l|l|}
\hline Length of membership & Frequency & Percentage \\
\hline Less than 1 year & 28 & 56 \\
\hline 1 to 2 years & 12 & 24 \\
\hline More than 2 years & 10 & 12 \\
\hline
\end{tabular}

The table 2 give details about length of membership in quality circle program, 56 percent of population are members in circle for less than one year, 24 percent of members were in circle for 1 to 2 years and 12 percent of members were in circle for more than 2 years.

Table 3- Training

\begin{tabular}{|l|l|l|}
\hline Perception of training & Frequency & Percentage \\
\hline $\begin{array}{l}\text { Low perception } \\
\text { (less than35) }\end{array}$ & 9 & 18 \\
\hline $\begin{array}{l}\text { Moderate perception } \\
\text { (35 to 45) }\end{array}$ & 29 & 58 \\
\hline $\begin{array}{l}\text { High perception } \\
\text { (above 45) }\end{array}$ & 12 & 24 \\
\hline
\end{tabular}

As per table 3results it is obvious that 18 percent of members have low perception about training, 58 percent of members have moderate perception and 24 percent have high perception about training provided by organisation. 
Table 4- Participation in Decision Making

\begin{tabular}{|l|l|l|}
\hline $\begin{array}{l}\text { Level of participation in decision } \\
\text { making }\end{array}$ & Frequency & Percentage \\
\hline Low level(less than 20) & 12 & 24 \\
\hline Moderate level (20 to 30) & 31 & 62 \\
\hline High level(30and above) & 7 & 14 \\
\hline
\end{tabular}

The table 4 indicate about participation in decision making among members of quality circle in organisation.24 percent of members say that they have low level of participation in decision making, 62percent employee have moderate level of participation in decision making, 14 percent members have high level of participation in decision making.

Figure 2.The EstimatedModel of SEM

Toidentify the interrelationship between variables structural equation model have been performed by using AMOX software. There are 14 items for training but after performing confirmatory factor analysis five items have been chosen for SEM. After performing confirmatory factor analysis for participation in decisions making three items have been chosen out of five items. All the three items of quality circle attitude and one item to measure length of membership have been chosen to perform structural equation model.

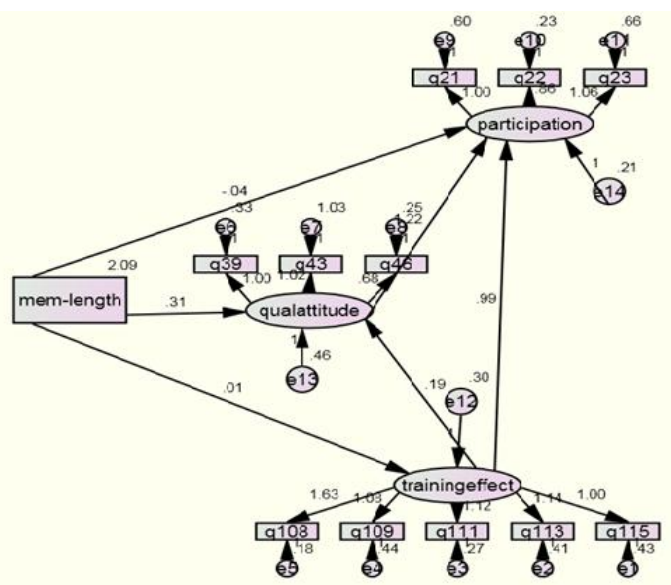

\begin{tabular}{|l|l|}
\hline Mem-lenght & Length of membership \\
\hline Training & Training increased skill \\
Q108 & Application of learnt skill of training \\
Q109 & Sufficient practice of program \\
Q111 & Program provides sufficient feedback \\
Q113 & Program exceeds expectation \\
Q115 & Quality circle members attitude \\
\hline Qc attitude & Effective in getting positive changes \\
Q39 & Benefits achieved in own work by QCs suggestions \\
Q43 & Suggestions developed by circle is implemented \\
Q46 & Participation in decision making \\
\hline Participation & Participation in job decision \\
Q21 & Allowed to influences in self work decision \\
Q22 & Supervisor ask opinion in decision affecting my work \\
Q23
\end{tabular}

Table 5- Parameters Estimates

\begin{tabular}{|l|l|l|l|l|l|l|}
\hline \multicolumn{1}{|c|}{ Description parts } & Estimate & S.E & C.R & P & $\begin{array}{l}\text { Direct } \\
\text { Effect }\end{array}$ & $\begin{array}{l}\text { Indirect } \\
\text { Effect }\end{array}$ \\
\hline Training effectiveness<--- length of membership & .012 & .057 & .216 & .829 & 0.012 & 0.000 \\
\hline Qc attitude<--- length of membership & .305 & .082 & 3.713 & $* * *$ & 0.305 & 0.002 \\
\hline Qc attitude<--- training effectiveness & .189 & .224 & .846 & .398 & 0.189 & 0.000 \\
\hline $\begin{array}{l}\text { Participation in } \\
\text { decision making<--- length of membership }\end{array}$ & -.043 & .110 & -.388 & .698 & -.043 & 0.411 \\
\hline $\begin{array}{l}\text { participation in decision } \\
\text { making <--- Qcattitude }\end{array}$ & 1.295 & .280 & 4.633 & $* * *$ & 1.295 & 0.000 \\
\hline $\begin{array}{l}\text { participation in } \\
\text { decision making }<--- \text { training }\end{array}$ & 1.043 & .314 & 3.325 & $* * *$ & 1.043 & 0.245 \\
\hline
\end{tabular}


Length of membership is not influencing training effectiveness in determining members participation in decision making.The maximum likelihood of this relationship is 0.012 and standard error is 0.057 with critical ratio 0.216 , the p-value 0.829 was found to be not significant.Hence the hypothesis $\mathrm{H} 1$ is rejected, length of membership doesn't play important role in training effectiveness and participation in decision making. This might be due to diminishing interest in QC activities and this is also supported by study of Griffen (1988) he also found that over a period of 3years, the effect of QC initially increased after about 18 months, the level of participation return to its initial level. To improve their level of participation in decision making management should support the QC program through disband of circle, improving effectiveness of training, attempt to increase the level of interest and enthusiasm through rewards system or modify the program by increasing members responsibility and authority participation of decision making.

Relationship does not exist between training effectiveness and quality circle attitude. The maximum likelihood estimate of this relationship is 0.189 and standard error is 0.224 with critical ratio 3.713 , the p-value is 0.398 which is not significant so hypothesis $\mathrm{H} 2$ is rejected. Though there is no significant relationship between QCs attitude and training effectiveness. Training effective influences at $0.1890 \mathrm{n}$ QCs attitude, the $\mathrm{r}^{2}$ estimates was found to be 0.126 .It is inferred that training effectiveness influence at 13 percent on quality circle attitude and remaining percentage influenced by other factors. This study is supported by study of RajeshChaudhary and LalitYadav (2012) he reveals that there are various factors involved in developing the employees attitude towards quality circle. The organization plays a facilitator role in developing Quality circle. The transparency and integrity of the organization is very much important for the smooth functioning of quality circles. The culture has great impact on the quality circles based on employee involvement, employee empowerment, perceived organizational support \& employee engagement.

Though maximum likelihood estimate relationship of QCs attitude and participation in decision making is 1.285 and standard error is 0.280 with critical ratio 4.633, the p-value is 0.000 which is significant but The maximum likelihood estimate of this relationship between training effectiveness and quality circle attitude is 0.189 and standard error is 0.224 with critical ratio 3.713 , the p-value is 0.398 which is not significant ,from the table value it is clear that QCs is not mediating the relationship between training effectiveness and participation in decision making so hypothesis 3 is rejected. But participation in decision making is mutually influenced by training effectiveness and quality circle attitude. This might be because,employees are interested in Quality Circle programme, merely when they believe that their participation benefits themselves and as well as organization. To facilitate they must be well trained in group dynamic and problem solving methods. Subsequently employees are benefited in terms of improved attitudes, moral, abilities, perceptive and communication. The organization also benefits in terms of improved quality and quantity productivity.

A positive relationship exists between training effectiveness and participation in decision making. The maximum likelihood of this relationship is 1.043 and standard error is 0.314 with critical ratio 3.325 , the p-value 0.000 was found to be significant, hence hypothesis 4 is accepted. This result is coincident with the study of Everett E A J (1991).

\section{Conclusion}

The study implies that participation in decision making among members of quality circle in manufacturing companies be improved through improving QCs attitudes and training. Though length of membership is not directly influencing participation in decision making howeverwith continuoussupport and motivation of management it could be improved. Although training and QCs attitudes of members are not mutuallyinfluencing participation in decision making but indirectly influencing decision making of members. This result shows that selected four variables have interrelated relationship with each other, still participation in decision making of members can be improved with support of management, facilitators and supervisors of quality circle. Modified training as per requirements for participation can be provided and this will improve the QCs attitudes of members, also lay concrete on success of quality circle.

\section{References}

[1] Alexander, C. Philip. (1981). Learning from The Japanese Personnel Journal, 60, pp 616-619.

[2] Atwater, Leanne, and Sander, Stephen. (1984), Quality circles in navy organizations: An evaluation. (TechnicalReport No. NPRDC TR 8453). San Diego, CA: Navy Personnel Research and Development Center(AD-A146613).

[3] Basu, R. (2004), Implementing quality: A practical guide to tools and techniques. London:Thomson.

[4] Dale, B. G., M.B.F. Elkjaer, A.V.D. Wiele and A.R.T. Williams, (2000). Fad, Fashion and Fit: An Examination of

[5] quality Circles, Business Process Re-Engineering and Statistical Process Control. ELSEVIER 73: 137-152 Int. Production Economics.

[6] Everett E A J(1991), Quality circle performance manage, 17 (1991) pp 25-39.

[7] Griffin, Ricky W. (1988), Consequences of quality circles in an industrial setting: A longitudinal assessment. Academy of Management Journal, 2, pp 338-358.

[8] KristensenKand Dahlgaard J J, (1991) quality motivation in East Asian countries, Total quality

[9] Lawler, E. E., S. A. Mohrman. (1987). Quality circles: After the honeymoon. Organ. Dynam. 15 pp $42-55$.

[10] Maheshwari, B.L. (1987), Quality Circles, Oxford \& IBH Publishing: New Delhi, p10. 
[11] Meyer, G. W., R. G. Stott. (1985). Quality circles: Panacea or Pandora’s box. Organ. Dynam. 13 pp 34-50.

[12] PetrosPashiardis(2000), Teacher Participation in Decision Making Doi: 10.1177/0018726700533003Human 2000 vol. 53 no. 3 pp 341-358.

[13] Rajesh Chaudhary, LalitYadav(2012) Impact of Quality Circle Towards Employees \& Organization a case study IOSR Journal of Engineering (IOSRJEN) e-ISSN: 2250-3021, p-ISSN: 2278-8719, www.iosrjen.org Volume 2, Issue 10 (October 2012), pp 23-29.

[14] Rathnakar.G (2012)A study of workers participation in management Decision making at bhel, Hyderabad International Journal of Marketing, Financial Services \& Management Research Vol.1 Issue 9, $\quad$ September 2012, ISSN 22773622.

[15] Reylito A H E (2003) labour and management, Business world, 2(2003)1.

[16] Shadur, M.A., Kienzle, R., \&Rodwell,J.J. (1999) The Relationship between Organizational Climate and EmployeePerceptions of Involvement: The Importance of support. Group and Organization Management, 24 (4); pp 479-503.

[17] Tang T L P \&Tollison P S(1993) difference between active and inactive quality circles in attendance andperformance,public personnel manage,22(1993) pp 579-590.

[18] Tortorich, R., Thompson, P., Orfan, C., Layfield, D.,Dreyfus, C., and Kelly, M. (1981). Measuring organizational impact of quality circles. The Quality Circles Journal, 4, pp 24-34.

[19] T R Abo-Alhol,M Y Ismail,S M Sapuan and M MHamdam (2006) effects of quality circle participation on employee perception and attitude in five Malaysian companies 2006.

[20] Wood R,Hull F and AzumiK,Evaluating (1983) quality circles:The American application,California manage Rev,26(1983) pp $37-53$. 